\title{
THE POLARITY OF THE GOSPELS IN THE EXEGESIS OF ORIGEN
}

Samuel Laeuchli, Arlesheim, Switzerland

In spite of all the hermeneutic research, the allegorizing of the Alexandrians, and above all the exegetical work of Origen, remains a strange phenomenon of the early church. Historians have often smiled indulgently, if they have not scoffed, at those childhood steps of biblical interpretation within ancient Christian theology, from Thomasius more than a century ago up to our present. ${ }^{1}$ The possibility of a complete understanding is hindered by the lack of many of Origen's texts in the original language. Many of his commentaries are lost. And yet there are certain indications from which we can learn that Origen did have his sound reasons for his exegetical undertaking. ${ }^{2}$ For this, one has to examine the tenth chapter of his Commentary on John.

In his lengthy fifteen chapter exegesis of the account of the cleansing of the temple, ${ }^{3}$ Origen begins by stating the fact that John presents the story in which Jesus chased the ox and dove dealers from the temple as the second "work" done by Christ, whereas the synoptics report a similar event toward the end of his life. ${ }^{4}$ This pericope is closely connected, in the synoptic tradition, with the entrance into Jerusalem (the colt, the Hosanna). In the fourth Gospel, however, this story appears much later, at another arrival of Jesus in the holy city. ${ }^{5}$ What the synoptics report as a continuous event, at one and the same arrival, is divided by John into two episodes separated by many happenings in different locations. ${ }^{6}$

The synoptic-johannine question! There can be no doubt that Origen clearly sees it and tries to formulate it. As he says himself, he wants to show "the discrepancy of the text (tên kata to rēton diaphōnian)." Two sources tell contradictory stories, and there is no way to combine the presentation of the synoptics with that of John. To harmonize this discrepancy is strictly impossible for one who does not recognize anything behind the mere history. ${ }^{7}$ Attempts had been made to harmonize the four gospels. ${ }^{8}$ In definitive contrast to Tatian and Theophilus of Antioch, here for the first time a theologian of the church realizes the full impossibility of any historical harmonization. ${ }^{9}$

Origen discovered not only the conflict within the evangelical tradition but also the unity of the synoptics against John, purposely quoting each at full length in order to bring out the tremendous 
contradiction which exists between them and the fourth Gospel. The three report the same event much later; what transpires at two arrivals in John, happens at one and the same arrival according to the three. One can imagine that the ingenuousness with which he deals with these not harmless matters would have been impossible within the formed and stabilized Christian church of only a few centuries later. To be sure, he senses the dangerous ground he is walking on: anyone who believes that he has not dealt honestly with this problem may reasonably write a refutation. ${ }^{10}$ This is a cautious hint, indeed, with a view to the tremendous bearings of the problem but still, to judge from what follows, more a rhetorical phrase than a sign of uncertainty.

Origen had two ways out of this blind alley: he could either choose one of the two versions as the true one by negating the historicity of the other-this would have been a question of probability and personal decision-or he had to deny the historicity of both versions. Origen chose the second. With theological freedom as well as sharp historical criticism he deprives the story of the cleansing of the temple of its historical authenticity: how could the son of a carpenter have dared to drive the merchant people with their doves and oxen from the temple? Would it not have been hubris for Jesus to scatter the money of the changers and to overturn their tables? If anyone had been struck by the scourge of cords, would he not have fought back, especially when a whole mob of people must have thought they had been treated unjustly? And finally, does it not seem presumptuous and daring to assert that the Son of God took a whip and made a scourge in order to chase people out of the temple ?11

Origen undertakes literary criticism with an audacity which sometimes reminds us of rather modern methods of biblical exegesis. There is only one historical fact at the basis of the story according to him: that in Lent merchants used to bring animals for the offering into the outer-court of the temple. This event has been used by the evangelists. ${ }^{12}$ The rest is not history. What pushed Origen to make such a critical judgment, so extreme and daring for his time?

From the very beginnings of the second century, the fact of a plurality of gospels had been perceived in the church as a weighty problem. ${ }^{13}$ Even though Irenaeus tried to create the pretence of a natural order for the existence of four separate Gospels, by pointing to the cosmic-holy quaternary number, the church always had to defend itself against the two attempts to solve the problem that were ever again repeated: either to accept only one of the four gospels (as Marcion did), or to take up a harmonization (Tatian was not the only one to try this, and his Diatessaron was so popular that 
it finally had to be forbidden by the bishops $).{ }^{14}$ By proving the full discrepancy, Origen makes every harmonization impossible. If he had chosen, however, either of the two,- - the synoptics or John-as the true source, he would have abandoned the ecclesiastical tradition of the equivalence of the Gospels, by admitting falsifications of one evangelist. Further, which is even more important, it would have been almost impossible for him to make a choice. To decide against the three synoptics would have been hard, and to eliminate the Alexandrians' most inspiring gospel was out of the question.

While criticizing the cleansing of the temple, Origen realizes that this story is connected directly, according to the synoptics, with the pericope of the entrance into Jerusalem. These two stories, their relationship and their divergency, create the whole historic problem which Origen faces here. Consequently, he turns his literary criticism against that second story. Again, some of the arguments are exceedingly weak (how could it be otherwise, his being the first serious exegetical attempt within the post-apostolic church?). Was it necessary to send two disciples into the village of Bethphage in order to find an ass and her colt? Was it worth recording that he entered the city sitting on an ass and her colt ? $^{15}$ An ass would not be worthy of the divinity of the Son. And besides, a journey of fifteen stadia is not long enough to justify the use of these animals, and why was it necessary to have two ${ }^{16}$ The main argument, however, sounds quite different: the Zechariah quotation should consist of Zech. 9:910. The evangelist quoted only Zech. 9:9 ("Rejoice greatly ... thy king cometh unto thee... riding upon an ass") and left out 9:10 ("I will cut off the chariot from Ephraim and the battle bow shall be cut off ...”). Now Zech. 9:10, says Origen, would not have been applicable to the act of Jesus' coming into the town-he did not destroy any chariots nor cut off any battle bow. Because this was not true historically (different, of course, is the anagogical aspect of the whole matter which Origen discusses thoroughly afterwards), it would be wrong to use the Zechariah text in respect to Jesus, for the Jews could embarrass the Christians seriously by asking us how Jesus destroyed chariots of Ephraim! ${ }^{17}$ For the first time, as far as we can see, a theologian of the $\operatorname{church}^{18}$ sets it forth as fact that a passage of the Old Testament has been used in the New Testament in a not completely correct way and opens therewith the modern discussion of such consequence about Gen. 3:15, Dt. 18:15, and Is. $7: 14,{ }^{19}$ although it took the church one and a half millennia to realize the gravity of this problem. Origen, of course, had no inkling of what kind of spirits he was letting loose in the church. $\mathrm{He}$ only claims, as he says, that the Zechariah text does not permit us to speak about a "somatic fulfillment." The starting point of this spe- 
cific criticism was not the realization of a wrong textual application itself but the necessity of depriving the Matthew passage of its historic ground.

The main discussion about the plurality of the gospels is found in the beginning of the tenth chapter of the Commentary on John. There Origen presents with uncompromising clarity the full discrepancy between John and the Synoptics. He develops it in his exegesis of John 2:12 ("He went down to Capernaum"), comparing it with the synoptic parallels which report that after the temptation Jesus went up to Galilee, stayed in Nazareth ${ }^{20}$ and came then to Capernaum to live there. ${ }^{21}$ Now it is simply impossible to bring these two versions together on any historic basis; the forty days of the temptation have no place at all in John! When did Jesus come to Capernaum? If he went down after the six days of his baptism (the sixth was the wedding of Cana) then he never was tempted, nor lived in Nazareth, nor was John the Baptist thrown into jail. And in Capernaum, according to John, he did not stay long, but departed for Jerusalem, where he drove the animals out of the temple. $^{22}$

This is the whole problem of the Gospel of John and the Synoptics: one excludes the other. And Origen did not close his eyes, as many modern exegetes do, dealing cleverly with the interpretation alone. He asks the decisive question: how can these both be true at the same time: that Jesus went to Galilee after the imprisoning of John the Baptist (Mark and Matthew) and (John), that he went to Capernaum right away and then to Jerusalem, while John the Baptist was still preaching in Aenon near Salim ? $^{23}$ How can two expositions which contradict each other both be true and retain their validity? What is historically contradictory cannot be historically true. And Origen knows well enough that this is not the only case where a discrepancy can be found; in many other places there is a "disharmony of history." 24 It is astonishing how well this early church exegete sees the problem. "How can both be true?" Here there is no synthesis any more, no possibility of eliminating one or the other. If we want to maintain the equal value of the gospels, we have yet to admit the historical disharmony. Origen makes every harmonisation impossible. Perhaps he thinks of the many of his time who still believe in Tatian's attempt in the Diatessaron. "Let them tell us," he says, "where the forty days of the temptation are to be found in John!"

What does Origen achieve with all this? With a slight irony Thomasius assumed that Origen started from the prejudiced opinion that in allegory he had "the key to Scripture," and that in order to substantiate this idea" he sought for contradictions in the texts where 
nobody would think of them. ${ }^{25}$ It is exactly the other way around! Not that we should deny the sometimes naive character of the constructions and arguments of which Origen makes use. But in the given passages he does not search for something that is not there; he discovers one of the greatest difficulties in the realm of the New Testament, a problem Thomasius and his whole age had not even seen. Origen does not create contradictions; he finds them. And even more, he sees them because he is aware of the consequences for a systematic theology. He did not start criticism because of some prejudice (why would this have been necessary?) but because he was looking for the theological truth of the gospel. And then he discovered the full paradox.

Exactly here we find the inner justification for Origen's allegorical method in the interpretation of the Scripture. Allegory had had already a long history, from the interpretations of Homer by the Greeks, to the Rabbinic exegesis; to Philo and the church fathers. ${ }^{26}$ And Origen of course, participates in this tradition. ${ }^{27}$ However, we cannot simply explain everything from historical dependence. ${ }^{28}$ There is in Origen a necessity for his allegorical method, a necessity which comes from the New Testament itself! And by this necessity he can justify his whole undertaking of interpreting the Scripture anagogically. "If we cannot solve the divergency, because of the plurality (of the gospels), ${ }^{29}$ we have to give up the belief in the gospels, assuming then that they are not true nor written in the divine Spirit ..."30 Those who do not believe that anagoge is the only way to solve the very apparent divergency, should tell us where to find in John the forty days of temptation. ${ }^{\mathbf{3 1}}$ There is the basis for his anagogical interpretation. For four gospels have to be kept as documents of the divine truth. They only remain such documents if they harmonize together; otherwise the divine truth breaks asunder. How can they harmonize, however, on historical grounds, if the contradictions lie visibly open? The interpreter must find the realm above history, above the literal text, in which the unity exists. The texts themselves urge him to do it, and driven by this necessity, Origen finds the answer: the truth lies in the noetic: tēn peri toutōn alètheian epikeisthai en tois noètois. ${ }^{32}$ In the realm to which anagoge leads him, unity is possible.

This urgency does not exclude the fact that Origen stands within the history of allegory. However, there is, beyond any slavish dependence, this inner basis from which we can well understand his whole undertaking, i.e., the problem which has remained to this very day a weighty question, perhaps not so much for the historian as for the systematic theologian. ${ }^{33}$ Because Thomasius, Denis and Eugène de Faye did not see this New Testamental basis, they could never understand the whole exegetical undertaking of Origen. ${ }^{34}$ If this 
polarity, developed in John Comm. $\mathrm{X}$, is but a fictional assumption, the criticism and the attempt to overcome the discrepancy would turn out to be a farce, indeed. Nowadays, we realize that this divergency is not simply a fiction and that it was not Origen, unfortunately, who has made up the contradictions. ${ }^{35}$

To show the unity of Holy Scriptures was one of the great goals of Origen's interpretation, to live in that eternal symphony of such manifold books, as the famous fragment of Matt. Comm. II so beautifully proclaims it. ${ }^{36}$ How he was forced from the historical paradox to achieve a solution, the apologetic situation shows. We know the pagan philosophical opinion about the Christian doctrine from Celsus and Porphyrius. ${ }^{37}$ This "superstitious sect" was ridiculed everywhere, and the heathen thinkers were always looking out for new targets. These unsympathetic critical eyes could not possibly miss for long the paradox within the central tradition of the Christian church. An attack from this direction, therefore, could soon become extremely dangerous for the defenders of the faith. Origen prevented this possible surprise by exposing the divergencies in their full rigor. But this was not enough. They still could have triumphed over the trivial contradictions within the reports about the life of God's Son. So Origen had to prove that there was a unity, by demonstrating the great harmony in the noetic realm. ${ }^{38}$

In this struggle of the Christian theologian against the manifold trends of pagan thinking, the vast majority of the uneducated believers created the greatest obstacle. There was a group of Christians, in the line of the first post-apostolic texts, which acknowledged neither criticism nor allegorism, proclaiming a moralistic and eschatological faith. These biblicists simply wanted to accept the text as such, refusing the pneumatic level in which Origen tried to reconcile the paradox. If they had succeeded, the way would have been open again for the pagan attack. For these reasons, Origen found himself in an apologetic situation, trying to show the impossibility of historical harmonization. For the first attempt at harmonization came precisely from these groups, from the author of the book against the Greeks! $!^{39}$

There is a third basis for Origen's apologetic stand in his rejection of Gnosticism. In spite of all his dependence upon, and relationship to, this second century movement, ${ }^{40}$ there was a decisive break from it in his being rooted in the tradition of the New Testament, in his existence as a member of the ekklesia. ${ }^{41}$ Every religious group in that age had to refer to a period of revelation, using holy scriptures which were regarded as absolute. Like everybody else, the Gnostics had done this too.

Clearly aware of the noticeable difference between their theo- 
ries and the New Testament, documents, they set to work to create their own gospels, new lives of Jesus. Now if the contradictions in the tradition about the Lord must remain utterly unsolved, the path was opened wide for new, "better" reports, and this meant for other gnostic speculations. For this reason again, therefore, Origen could by no means ignore the discrepancies, but must explain to his readers how great a unity bound the four gospels together. His method led him to it, and without necessity for creating new gospels or for searching for other documents, provided him with the means of killing the gnostic claims of the insufficiency of Scripture.

These three worlds, pagan philosophy, Fundamentalism, and Gnosticism, in turn forced Origen to the necessity of an interpretation beyond the historical text. Even more, they gave him the justification for it. He had to be able to defend the documents which were the foundations of the young church. There is something in his theology from each of the three, no doubt: he possesses the Greek desire for and conception of truth and cannot get rid of a good number of Hellenistic elements ;2 he owes important ideas to the Gnostics $;^{43}$ and, in spots, we notice a strange fundamentalism in his exegesis. ${ }^{44}$ But, in his central position, he is neither a Greek nor a Gnostic nor a Fundamentalist. By his anagogical interpretation he defends his ecclesiastical theology against each of the three.

There is an important question one might ask in respect to the beginning of the tenth chapter of the Commentary on John. In Peri Archon Origen postulates an explanation for the fact that in some passages unhistorical events are to be found: the evangelists purposely wove unhistorical stories into the historic facts. ${ }^{45}$ Let us assume, he says, four persons who, in the spirit, all see God. Each of these will report this epiphany in his own way. The time may be the same, but the exact words and location may differ in each account (one sees God standing in a certain place, while another sees Him somewhere else sitting and saying quite different words.) ${ }^{46}$ It is always the same vision, and the same God. The disharmony disappears as soon as we recognize that the historians wanted to teach by a sign (charak$t e r r$ ) what they have seen in the spirit. In a mystical intention (mustikos skopos) they weave into the aisthèton (i.e., into their presentation of what one perceives with the senses) that which they perceived purely noetically. ${ }^{47}$ One finds here two arguments which originally do not belong together. God is beyond the human categories of space and time. He can reveal himself to two separate persons at the same time, whereby this, revelation is not at all devaluated by any discrepancy which might arise. The earthly contradiction becomes a divine harmony because God in his noetic nature is not bound to human presuppositions. ${ }^{48}$ This approach to the biblical discrepancies, however, 
especially as applied to the New Testament, could turn out to be exceedingly dangerous. For Jesus had no purely noetic nature but existed in flesh and blood. If this argument is carried through, all the doors are opened for a docetic christology. ${ }^{49}$ So the other theory arises which could be applied with less danger to the tradition about Jesus: the biblical authors wove the unhistorical into the historical texts. The docetic misunderstanding is thereby precluded.

In the account of the cleansing of the temple, we see perfectly well how Origen utilized this theory: the whole pericope was made up and never actually happened. In his exegesis of John 2, 12 he demonstrates very obviously how John and the synoptics disagree with regard to the main trends in the life of Jesus. He does not, however, apply his principle here. At least, he does not carry it through. Not once does he return to the question of the forty days' temptation from which he started. Had he applied this principle here, he would have had to say that all these divergent passages had been purposely woven into the historical account, only the pneumatic element within being true. Origen did not dare to take this step, in spite of his deep understanding of the critical questions in the New Testament. ${ }^{50}$ The reason for this lies again in his apologetic interest. The philosophers were perhaps willing to accept Jesus as a mythological figure (like Adonis, Isis, Mithras), and the Gnostics spoke about spirit till matter ceased to exist. Origen did not want to surrender, consequently, such a considerable part of the historical Jesus. This is the reason why he did not decide whether the forty days of the temptation or the going up to Jerusalem was woven into the history by the evangelists.

The Origenistic exegesis contains a good many riddles for the modern interpreter. It belongs to a long tradition of the same kind of explanation. It is involved in Origen's terrific struggle for a Christian theology and stands at the beginning of a long history of ecclesiastical exegesis. One of the astonishing factors in it is his realization of the polarity of the gospels, not alone of the polarity itself (Tatian and Clement of Alexandria saw this also) but of the problem of this polarity. What happens to the believer if he takes both the history and the theology seriously, trying to combine the historical moment of the Christian revelation with its content, without falling either into a docetic mysticism or into a moralistic humanism? It speaks for the greatness of Origen that he saw and honestly expressed this tremendous tension. In it one finds the justification for his allegorical method. Because he could give up neither historicity nor the claim of an absolute truth (both being essential elements of Christianity), he had to find a realm above history in which the historical text could be interpreted. This is the sine qua non of his exegesis. 
1 Gottfried Thomasius: Origenes, ein Beytrag zur Dogmengeschichte des dritten Jahrhunderts, Nürnberg 1837 pp. 311 sqq. ("willkürlich ... masslos") Luther: $W A$ Tischr. I (Weimar 1912) p.106, Jacques F. Denis: De la philosophie d'Origène, Paris 1884 ("Id́és abstruses, Jeu d'imagination, Formes de la liberté de la pensée'") pp. 33sq. Bigg: The Christian Platonists of Alexandria, London 1886 ("The Alexandrine method as applied by Origen is undoubtedly unsound"... "Such Paltering with the text is not honest'"! 1) pp. 146sqq. Lately: Cumont: Recherches sur le symbolism funéraire des Romains, Paris 1942. As for the history of the interpretation of Origen's exegesis see: De Lubac: Homélies sur la Génèse, Introduction. Paris 1943.

2 Ernst Rudolf Redepenning: Origenes, eine Darstellung seines Lebens und seiner Lehre (2 vol.) Bonn 1841-46 already recognized that only Origen himself would be able to show us the reason for his interpretation, and that within it, the Seripture itself will give us the decisive basis. Pp. 322 sqq. Therefore, there is no condemnation ex cathedra in Redepenning, in contrast to so many others.

3 John Comm. X, 20-34 (Between the referenees in $\mathrm{GCS}$ ).

4 Ibid. X, 20 [119].

5 Ibid. X, 21 [123-128].

6 Ibid. X, 22 [129].

7 Ibid. X, 23 [130].

8 Cf. Oscar Cullman: Die Pluralität der Evangelien als theologisches Problem im Altertum (Theol. Zeitschrift d. Univ. Basel 1945, Heft I).

9 Clement with his distinction of bodily and spiritual gospels and Marcion with his choice of one gospel perhaps had an inkling too.

10 John Comm. X, 23 [130].

11 Ibid. [145-147].

12 Ibid. X, 25 [144].

13 Cf. Cullman: op. cit.

14 Jerome: $\boldsymbol{E p}$. 121, 6, 15.

15 John Comm. X, 26 [159-160a].

16 Ibid. [165, 164].

17 Ibid. [163].

18 One might assume a direct or an indirect influence from Marcion or the Gnostics. However, this is hard to prove.

19 One thinks of Wilhelm Vischer: Das Christuszeugnis des Alten Testamentes 1934-42 and the rejection of his opinions by the plurality of Old Testament scholars.

20 Origen has for Nazareth Nazara: (John Comm. X, $2[9], X, 11$ [50]).

21 Ibid. X, 1-2: Matth. 4, 1 c. par.

22 Ibid. $\bar{X}, 3$ [10b-11].

23 Ibid. $X, 3$ [13].

24 Ibid. $X, 3$ [14].

25 Thomasius: op. cit. p. 33. Cf, also Redepenning op. cit. vol I. p. 316 .

26 Cf. for this: Daniélou: Origène, Paris 1948 pp. $175-190$.
27 Redepenning did see this: op. cit. vol. I p. 297.

28 Bigg realized that one cannot understand Origen simply from his historical presuppositions. He therefore also separates him distinetly from Clement of Alexandria: op. cit. p. 134. Also Henri de Lubac: "Entre Plilon et Orjgène, il y a tout le mystère chrćtien!" Homélies sur l' Exode pp. 15 sqq.

29 The addition by Preuschen: dia tous pollous is evident.

30 John Comm. X, 3 [10a].

31 Ibid. $\mathrm{X}, 3$ [106a].

32 Even if the beginning of $X, 2$ is corrupted (ef. the footnote in Preusehen's edition), its meaning is perfectly clear.

33 Beside Henri de Lubac, Preuschen (in his introduction to the eritical edition of the Commentary on John) has strongly, defended Origen against the reproach of a technical taking over of the Alexandrian allegorism. " . . nicht nur gedankenlose Nachahmerei ....? he says: p. LXXXIII.

34 'Thomasius did not know what to make out of John Comm X, lsqq. op. cit. p. 316. The best Denis could say was: "Origène ne déprime la lettre que pour mieux faire sentir la necéssité de chercher sous le sens historic un sens spiritual" pp. 36-40 op. cit., and Eugène de Faye called Origen's exegetical work an "unbelievable illusion" op. cit. vol. I p. 95. Redepenning has been considerably more careful: op. cit. vol. I p. 292. In his work about the exegesis of Origen, J. Prat: Origène, 1908, misses completely the critical aspects and does not speak about the historieal problems at all, just mentioning John Comm. $X, 5$ in a footnote (pp. 130133).

35 Without knowing exactly these reasons, Redepenning was right in postulating that the Seripture itself had to furnish the explanation for the exegetical attempts of Origen: op. cit. vol. I p. 322.

36 Philocalia VI, 2 (ed. J. Robinson, Cambridge 1893 ).

37 Cf. Eusebius: Hist. Eccl. VI, pp. 19 sqq.

38 For this apologetic side of allegorism ef. Bigg: op. cit. pp. 139 sqq. If there is a negative and a positive side of allegorism, as Bigg suggests (the first being apologetic, and the second for the discoveries of mysteries), these two aspects are almost identical in the question of the polarity of the gospels.

39 One finds therefore Origen opposed to both at the same time, to the Diatessaron and the Contra Hellenes.

40 Peri Archon is called a "System patristischer Gnosis"' by Hans Jonas in Theol. Zeitschr. d. Univ. Basel, 1947, Heft 2.

41 Cf. the discussion about Heraclion's com- 
mentary in Origen's Commentary on John.

42 Hal Koch: Pronoia and Paideusis, Studien über Origenes und sein Verhältnis zum Platonismus Leipzig 1932.

43 Cf. Hans Jonas: loc. cit.

44 In John Comm. VI, 30-39 for instance, Origen compares the words by John the Baptist about his not being worthy to unloose the latehets of the Messiah (John 1, 26-27) with its parallel texts: Matth. 3, 11, Mark 1, 7sq. and Luke 3, 15sq. Analyzing every little difference (the mentioning of the penance in Matthew, the different order of words, the diserepaneies), he comes to the conclusion that those reported sentences by the Baptist could not possibly go back to one and the same event. Otherwise, Origen says, we should have to assume that the evangelists erred and reported wrong details. (VI, 34) For it is not the same "to unloose the latchets" and "to bear the shoes," the first being told by Matthew, the second by Mark, Luke and John. John the Baptist has spoken both, at different oc- casions, in order to express each time something specific. And Origen tries to find the explanation and the connection of the two: the two versions represent two stages within the life of a Christian. First, he kneels down in order to unloose the latehets, then, however, he achieves the unloosing of his shoes, separating himself from the shoes, ie. from the earthly. The kupsas of the first version does not exist anymore in the second. This is no doubt a highly literal treatment of Scripture. Nevertheless, it shows us how utterly seriously Origen takes the diserepancies of the New Testament.

45 John Comm. X, 5 [18] P. A. IV 3, 4. 46 John Comm. $X, 4$.

47 John Comm. $\bar{X}, 5$.

$48 \mathrm{He}$ does not work para but huper tên phusin K. K. V 23.

49 Right afterwards (John Comm. X, 6) he struggles with vehemence against the Gnostic docetism.

$50 \mathrm{Had}$ he done so, he would have had to give up perhaps half of the gospel material. 